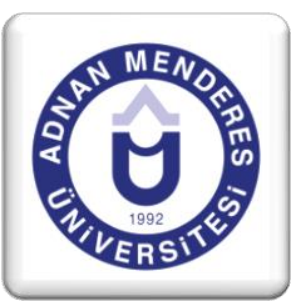

\title{
Sosyal Güvenlik Kurumları Açısından İllerin Analizi: MOORA Yöntemi ${ }^{1}$
}

\author{
Ersin YAVUZ ${ }^{2}$, Tahsin AVCI ${ }^{3}$, Abdullah Emre \\ ÇAĞLAR ${ }^{4}$
}

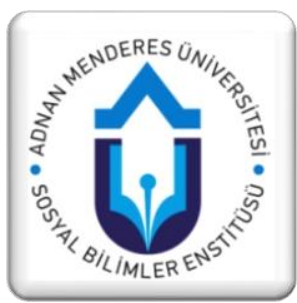

\section{ÖZET}

Bu çalışmanın amacı, Türkiye'deki 81 ili sosyal güvenlikle ilgili çeşitli rasyoları baz alarak etkinliklerine göre analiz etmektir. Çalışmada analize tabi tutulan değişkenler şunlardır: Sosyal güvenlik kapsamının il nüfusuna oranı, sosyal güvenlik kapsamındaki aktif çalışanların il nüfusuna oranı ve iş yeri sayısı çıktı olarak, sosyal güvenlik kapsamındaki bakmakla yükümlü tutulanların il nüfusuna oranı ve sosyal güvenlik kapsamındaki emeklilerin il nüfusuna oranı ise girdi olarak ele alınmaktadır. Çalışmada etkinlik analizi ise MOORA Yöntemleri ile yapılmaktadır. Bu yöntemi diğer çok kriterli karar verme tekniklerinden ayıran özellik yeni bir yöntem olması, basitlik, matematiksel işlemlerin miktarının az olması ve güvenilir olmasıdır. Çalışmada elde edilen bulgular incelendiğinde iki faklı yöntemle yapılan sıralamada ilk beş sırada yer alan illerin genellikle aynı olduğu görülmektedir. Bu iller; İstanbul, Ankara, İzmir, Antalya ve Bursa'dır. Bu illerde işgücü ve iş yeri sayısının fazla olması, etkinliği artırmaktadır. Nüfusun kalabalık olmadığı, çalışan sayısının az olduğu küçük şehirlerin ise sıralamada sonlarda yer aldığg sonucuna varılmaktadır. Ülkemizde üretimin ve hizmetin en fazla olduğu bu büyük şehirlerin sıralamada ilk beşte yer alması analizin sonuçlarının güvenilirliğini ortaya koymaktadır.

Anahtar Kelimeler: Sosyal Güvenlik Kurumu, MOORA yöntemi, Etkinlik.

JEL Kodları: B23, H55, R15

\section{Analysis of Provincials in Terms of Social Security Institutions: MOORA Method}

\begin{abstract}
The aim of this study is to analyze 81 provinces in Turkey according to their activities on the basis of various rations related to social security. The variables analyzed in the study are: The ratio of social security coverage to provincial population, the ratio of active employees covered by social security to provincial population and the number of workplaces are taken as output, while the ratio of the population covered by social security to the provincial population and the ratio of the pensions under social security to the provincial population are considered as input. Activity analysis is done by MOORA methods. This feature is a new method that distinguishes it from other multi-criteria decision making techniques, simplicity, low amount of mathematical operations and reliability. When the findings obtained in the study are examined, it is seen that the first five rows in the order of two different methods are generally the same. These include; Istanbul, Ankara, Izmir, Antalya and Bursa. In these provinces, the number of workforce and workplaces is high is the reason for increasing the efficiency. Small cities which are low population and a low number of employees are at the end of the list. These big cities, which have the highest production and service in our country, take place in the first five rows, reveals the reliability of the results of the analysis.
\end{abstract}

Keywords: Social Security Institution, MOORA Method, Efficiency

JEL Codes: B23, H55, R15

\footnotetext{
${ }^{1}$ Bu çalışma, daha önce 27-29 Temmuz 2017 tarihinde Adnan Menderes Üniversitesi tarafindan düzenlenen EUREFE'17 Uluslararası Kongresi'nde özet bildiri olarak sunulmuştur.

${ }^{2}$ Araştırma Görevlisi, Pamukkale Üniversitesi, İ.İ.B.F., Maliye Bölümü, ersiny@pau.edu.tr

3 Öğretim Görevlisi, Pamukkale Üniversitesi, Çivril Atasay Kamer MYO Finans Bankacılık ve Sigortacılık Bölümü, Bankacılık

ve Sigortacılık programı, Öğretim Görevlisi, tavci@pau.edu.tr (Sorumlu yazar)

${ }^{4}$ Araştırma Görevlisi, Akdeniz Üniversitesi, İ.İ.B.F, Ekonometri Bölümü, aecaglar@akdeniz.edu.tr
} 
1. Giriş

İçinde bulunduğumuz yüzyılın en önemli sorunlarından birisi işsizlik olarak görülmektedir. İssizlikten kaynaklanan ve bireylerin hayatlarına olumsuz yönde yansıyan birçok sorun bulunmaktadır. $\mathrm{Bu}$ sorunların başında sosyal güvenlik gelmektedir. $\mathrm{Bu}$ kapsamda hükümetler, sosyal güvenlik sistemi dışında kalanları minimize edecek politikalar geliştirmektedirler.

Diğer ülkelerde olduğu gibi Türkiye'de de işsizlik ve sosyal güvenlik önemli sorunların başında gelmektedir. Genel Sağlık Sigortası uygulaması, asgari ücret desteği, İŞKUR kapsamında iş edindirmeye yönelik uygulanan programlar, girişimciler ve KOBİ'lere yönelik verilen hibe ve krediler, bölgelerarası gelişmişlik düzeyine göre verilen teşvikler, Türkiye'de sosyal güvenliğin gelişmesi yönünde atılan önemli adımlardan bazılarıdır.

Çalışmada, Türkiye'nin sosyal güvenlik etkinliği iller bazında analiz edilmektedir. İlleri analiz ederken ampirik metod olarak MOORA Oran ve MOORA Referans kullanılmaktadır. Çalı̧̧manın iller özelinde olması, Türkiye'deki sosyal güvenlik sisteminin etkinliğine ilişkin daha detaylı bilgi sağlayacak ve daha isabetli politikaların geliştirilmesine imkan tanıyacaktır.

\section{Sosyal Güvenlik Kavramı ve Tarihsel Gelişimi}

Sosyal güvenlik kavramı, bireylerin günlük yaşantıda karşılaşabilecekleri ekonomik ve sosyal sorunlarına karşı ihtiyaç duyulan bir yapıdır. İnsanların hastalık, işsizlik, yaşlılık, ölüm vb. nedenlerle ortaya çıkan olumsuzluğa karşı toplumların kendilerini koruma amaçlı kurulmuştur. Sosyal güvenliğin tarihsel gelişiminde en önemli olay sanayi devrimidir. Sanayileşmenin doğurduğu risklere karşı sosyal güvenliğin önemi artmıştır. Sanayi devriminden öncede sosyal güvenliğin var olduğu bilinmektedir (Güvercin, 2004: 89-90).

\section{1. Ülkemizde Sosyal Güvenliğin Tarihsel Gelişimi}

Türkiye Cumhuriyeti'nin, Osmanlı İmparatorluğu'ndan aldığı sosyal güvenlik mirası, esas olarak, hayır ve yardımseverlik anlayışına dayalı sınırlı ve geleneksel olarak tanımladığımız güvence mekanizmalarını içermektedir. Cumhuriyet döneminin ilk iş yasası olan 1936 tarihli 3008 Sayılı Yasa ise, sosyal sigortaların kademeli olarak kurulmasını öngörmüş, ancak ilk sigorta kollarının ortaya çıkması için on y1l beklemek gerekmiştir (Gökbayrak, 2010:144145)

Sosyal sigortalarla ilgili ilk yasa 27 Haziran 1945 tarih ve 4772 sayılı İş Kazaları, Meslek Hastalıkları ve Analık Sigortaları Kanunu'dur. Bu yasaya paralel olarak 16 Temmuz 1945 tarihinde İşçi Sigortaları Kurumu Kanunu çıkarılmıştır. 2 Haziran 1949 tarihinde 5417 sayılı İhtiyarlık Sigortası Kanunu çıkarılmış, daha sonra 1957 yılında Maluliyet, İhtiyarlık ve Ölüm Sigortaları Kanunu kabul edilmiştir. 1950 yılında Hastalık ve Analık Sigortaları Kanunu çıkarılmıştır (SSK, 1999: 2-5).

Ülkemizde, sosyal güvenlik sisteminin; "kapsamı gittikçe genişlemekte", "sosyal sigortalar (Primli Sistem), sosyal yardimlar ve sosyal hizmetler (Primsiz Sistem) olarak 3 yönteme dayanmakta", "norm ve standart birliğinin sağlanmasına çalışılmakta" ve "finansmanı üçlü katklya (işveren-iş̧̧i-Devlet)" dayanmaktadır. Günümüzdeki sosyal güvenlik sistemini genel olarak 2006 yılı öncesi ve sonrası olarak ikiye ayırmakta yarar görülmektedir. Zira, 2006 
yılından itibaren daha önce başlatılan sosyal güvenlik reformu çalışmaları yasal zemine indirgenmiştir. Genel sağlık sigortası alanında ise 2008 yılında yürürlüğe giren 5510 sayılı Kanunun yürürlük tarihi itibarıyla mevcut kamu görevlileri dışında çalışanlar ile emekliler hemen kapsama alınmış, diğer bazı statüde olanların ise kademeli olarak ve nihayetinde 1/1/2012 tarihi itibarıyla tüm Ülke nüfusunun zorunlu olarak genel sağlık sigortas1 kapsamına alınması öngörülmüştür. Bu uygulama ile de, Ülke'de yaşayan ister vatandaş, ister yabanc1 (belli şartlarda) ister çalışan-çalı̧̧mayan ister emekli herkes genel sağlık sigortası kapsamına alınarak eşit sağlık hizmeti verilmeye başlanmıştır. Ülkemizde sosyal güvenlik reformu ile birlikte sosyal güvenlik sisteminin kapsamı üç ana koldan oluşturulmuştur. Bunlar; "Kısa Vadeli Sigorta Kollarl”, "Uzun Vadeli Sigorta Kolları" ve "Genel Sağglı Sigortası"dır (Levent, 2013).

\section{Literatür Taraması}

Tablo 1'de, MOORA yöntemine ilişkin literatürde yapılan önemli çalışmalardan bazıları yer almaktadır. $\mathrm{Bu}$ çalışmalarda MOORA yönteminin çeşitli versiyonlarının kullanıldığ görülmektedir.

Tablo 1. MOORA Yöntemini Kullanan Çalışmalar

\begin{tabular}{|c|c|c|c|}
\hline Yazarlar & Değişkenler & Modeller & Amaç ve Bulgular \\
\hline $\begin{array}{l}\text { ERSÖZ ve } \\
\text { ATAV } \\
\text { (2011) }\end{array}$ & $\begin{array}{l}\text { Farklı pencere ve } \\
\text { duvar alanlarından } \\
\text { oluşan alternatifler } \\
\text { arasından optimum } \\
\text { tercihi yapmaktır. }\end{array}$ & $\begin{array}{l}\text { MOORA } \\
\text { Modeli }\end{array}$ & $\begin{array}{l}\text { Bu çalışmada, } 2006 \text { yılında geliştirilmiş Çok Kriterli Karma } \\
\text { Verme problemlerinin çözümüne cevap veren ve yeni bir } \\
\text { yöntem olan MOORA (Multi-Objective Optimization by Ratio } \\
\text { Analysis) yöntemi incelenmiştir. Bina 1S1 kayılarının } \\
\text { derecelendirmesine ilişskin: binalarda meydana gelmekte olan } \\
\text { 1S1 kayıplarını inceleyerek derecelendirmek ve farklı pencere } \\
\text { ve duvar alanlarından oluşan alternatifler arasından optimum } \\
\text { tercihi yapmaktır. Çalışmada MOORA yöntemlerine ilişkin } \\
\text { farklı metotlardan elde edilecek sonuçların, çoklu olarak nasıl } \\
\text { değerlendirileceği ve MOORA metodunun sonuçları elde } \\
\text { edilmiştir. }\end{array}$ \\
\hline $\begin{array}{l}\text { YILDIRIM ve } \\
\text { ÖNAY } \\
\text { (2013) }\end{array}$ & $\begin{array}{l}\text { Bulut depolama } \\
\text { hizmeti veren beş } \\
\text { firma, on kritere } \\
\text { göre } \\
\text { değerlendirilecektir. } \\
\text { Alternatif ve } \\
\text { kriterler "The State } \\
\text { of Cloud Storage } \\
2013 \text { Industry } \\
\text { Report" başliklı } \\
\text { raporda belirlenmiş } \\
\text { olan firmalar ve } \\
\text { kriterlerdir. }\end{array}$ & $\begin{array}{c}\text { Bulanık AHP } \\
\text { ve MOORA } \\
\text { Modeli }\end{array}$ & $\begin{array}{l}\text { Referans alınan raporda firmaların bir sıralaması } \\
\text { yapılmamıştır. Fakat ilgili raporda yapılan testlerde en iyi } \\
\text { performansı gösteren firmayı belirtmiştir. Önceki yılda en iyi } \\
\text { performansı gösteren firmanın adı da verilmiştir ve yıllık } \\
\text { raporlar yayınlandığından beri her yıl farklı firmanın en iyi } \\
\text { performansı gösterdiği, bu sektörün hızlı gelişen bir Pazar } \\
\text { olduğu belirtilmiştir. Rapordaki en iyi performansı gösteren } \\
\text { firma ile bu çalışmada MOORA yöntemi ile yapılan } \\
\text { sıralamada birinci sırada çıkan firma aynı firmalardır. }\end{array}$ \\
\hline $\begin{array}{c}\text { DAS vd. } \\
\text { (2013) }\end{array}$ & $\begin{array}{l}\text { Çıktı: fakülte gücü, } \\
\text { öğrenci alımı, } \\
\text { doktora derecesi, } \\
\text { başvurulan patent } \\
\text { sayısı, kampüs alanı } \\
\text { Girdi: dönem başı } \\
\text { öğretim ücreti }\end{array}$ & $\begin{array}{l}\text { MOORA ve } \\
\text { Multi- } \\
\text { MOORA } \\
\text { Ağırlıklandır } \\
\text { ma için ise } \\
\text { AHP yöntemi }\end{array}$ & $\begin{array}{l}\text { Hindistan'da bulunan } 7 \text { tane teknoloji enstitüsünün } \\
\text { performansının ölçümü yapılmıştır. MOORA yöntemi } \\
\text { uygulanmadan önce karar matrisi üzerinden AHP yöntemiyle } \\
\text { uzman görüşü alınarak, sübjektif ve objektif ağırlıklandırma } \\
\text { yapılmıştır. AHP ve COPRAS ile elde edilen etkinlik } \\
\text { sıralamasını ayrıca MOORA yöntemiyle yapılan sıralama } \\
\text { kıyaslanmışıtır. Elde edilen bulgular neticesinde her iki } \\
\text { yöntemle bulunan etkinlik sıralaması birbirlerine çok yakın } \\
\text { sonuçlar vermiştir. }\end{array}$ \\
\hline
\end{tabular}




\begin{tabular}{|c|c|c|c|}
\hline $\begin{array}{l}\text { ÖZÇELIK ve } \\
\text { ATMACA } \\
\text { (2014) }\end{array}$ & $\begin{array}{l}\text { Kalite, Teslimat, } \\
\text { Üretim imkânları ve } \\
\text { teorik üretim } \\
\text { kapasitesi } \\
\text { Fiyat } \\
\text { Tamir-bakım } \\
\text { Yönetim ve } \\
\text { organizasyon }\end{array}$ & $\begin{array}{l}\text { MOORA ve } \\
\text { Multi- } \\
\text { MOORA }\end{array}$ & $\begin{array}{l}\text { Çalışma, kalite, geri bildirim hizmeti, paketleme yeteneği gibi } \\
\text { nitel kriterler için uzmanlardan } 1 \text { ila } 10 \text { arasında puanlama } \\
\text { yapmaları istenmiş ve sonuçta uzman görüşlerinin geometrik } \\
\text { ortalaması alınarak her bir alternatif için kriterlerin skorları } \\
\text { belirlenmiştir. Bu çalışmada, MOORA ve Multi-MOORA } \\
\text { optimizasyon teknikleri, tedarik zincirinde dış kaynak } \\
\text { kullanımına ilişkin bir seçim probleminde alternatifleri } \\
\text { sıralamak için kullanılmı̧şı. Bütün MOORA teknikleri, tam } \\
\text { çarpım formu ve nihayetinde tüm yöntemlere bakılarak baskın } \\
\text { alternatifin belirlendiği Multi-MOORA tekniği ile oluşan sıra } \\
\text { incelendiğinde, en iyi alternatifin E alternatifi olduğu } \\
\text { görülmektedir. Tüm yöntemlere göre analiz sonuçları Şekil } \\
\text { 1'de gösterilmiştir. Bu çalışmada, MOORA yöntemlerinin } \\
\text { seçim problemleri için etkili ve kolay kullanımlı bir ÇKKV } \\
\text { yöntemi olduğu gösterilmiştir. }\end{array}$ \\
\hline $\begin{array}{l}\text { AKTEPE ve } \\
\text { ERSÖZ } \\
\text { (2014) }\end{array}$ & $\begin{array}{l}\text { Çalış̧ma kapsamında } \\
\text { depo yeri seçimi } \\
\text { için, } 6 \text { ana kriter ve } \\
5 \text { alt kriter } \\
\text { belirlenmiştir. }\end{array}$ & $\begin{array}{l}\text { AHP-VIKOR } \\
\text { ve MOORA } \\
\text { Modeli }\end{array}$ & $\begin{array}{l}\text { Bu çalışmada, depo yeri seçimine karar verme konusunda } \\
\text { yöneticilere destek olacak yeni bir model geliştirilmiştir. } \\
\text { Uzman görüşlerine göre belirlenen seçim kriterlerinin } \\
\text { ağırlıklandırılmasında AHP tekniği kullanılmıstır. } \\
\text { Alternatiflerin sıralandırılması için ise çok ölçütlü karar verme } \\
\text { yöntemlerinden biri olan VIKOR ve çok amaçlı optimizasyon } \\
\text { yöntemlerinden biri olan MOORA yöntemleri kullanılmıştır. } \\
\text { Çalışma sonucunda, alternatif depo yerleri için iki ayrı model } \\
\text { kurulmuş olup, iki ayrı sonuç üretilmiştir. }\end{array}$ \\
\hline $\begin{array}{l}\text { TEPE ve } \\
\text { GÖRENER } \\
\text { (2014) }\end{array}$ & $\begin{array}{c}\text { Mezuniyet, } \\
\text { Bilgisayar } \\
\text { Kullanımı, Yeterlilik } \\
\text { Düzeyi Yabancı Dil } \\
\text { Seviyesi, İş Tanımı } \\
\text { ile İlgili Üretilen } \\
\text { Projeler, Tecrübe, } \\
\text { Referanslar, Yüz } \\
\text { Yüze Görüşme, } \\
\text { Mülakat, Sosyal } \\
\text { Aktiviteler, } \\
\text { Değerlendirme Testi }\end{array}$ & $\begin{array}{l}\text { AHP ve } \\
\text { MOORA } \\
\text { Modeli }\end{array}$ & $\begin{array}{l}\text { Bu çalışmada ülkemizdeki kurumsal bir şirketin personel seçim } \\
\text { süreci ele alınmıştır. Değerlendirmede dikkate alınacak ölçüt } \\
\text { ağırlıkları analitik hiyerarşi süreci (AHS) ile hesaplanmış, } \\
\text { sonrasında MOORA yöntemi kullanılarak personel seçimi } \\
\text { gerçekleştirilmiştir. }\end{array}$ \\
\hline $\begin{array}{l}\text { TÜRE vd. } \\
\text { (2016) }\end{array}$ & $\begin{array}{c}22 \text { makroekonomik } \\
\text { ve politik risk } \\
\text { göstergesi }\end{array}$ & $\begin{array}{l}\text { Oran } \\
\text { Yaklaşımı, } \\
\text { Referans } \\
\text { Noktası } \\
\text { Yaklaşımı ve } \\
\text { Tam } \\
\text { Çarpımsal } \\
\text { Yaklaşım } \\
\text { olmak üzere } \\
\text { üç alt } \\
\text { yaklaşımı } \\
\text { temel alan } \\
\text { Multi- } \\
\text { MOORA } \\
\text { yöntemi } \\
\text { kullanılmıştır. }\end{array}$ & $\begin{array}{l}\text { Çalışmada } 76 \text { ülkenin } 2012 \text { y1lına ait } 22 \text { makroekonomik ve } \\
\text { politik risk göstergesi bütüncül olarak değerlendirilmiş ve } \\
\text { ülkelere ilişkin risk sıralaması elde edilmiştir. Objektif olarak } \\
\text { elde edilen bu sıralamaya göre Lüksemburg, Singapur ve } \\
\text { Norveç ilk üçte yer alıken 56. sirada yer alan Türkiye'nin } \\
\text { ekonomik göstergelerinin başarılı olmasına rağmen gerilerde } \\
\text { yer almasının politik risk değişkenlerinden aldığı düşük } \\
\text { notlardan kaynaklandığı söylenebilir. Bu notların siyasi } \\
\text { olmadı̆ğ varsayımı altında "Politik İstikrar ve Şiddet / } \\
\text { Terörizm Olmaması" ve "Konuşma Yetkisi ve } \\
\text { Denetlenebilme" değişkenlerine ilişkin puanların iyileştirilmesi } \\
\text { Türkiye'nin daha yüksek sıralarda yer almasını sağlayacaktır. }\end{array}$ \\
\hline
\end{tabular}

\section{Veri Seti ve Metodoloji}

Çalışmada, Türkiye'nin 81 ili analiz edilmektedir. İller analiz edilirken kullanılan değişkenler şu şekildedir: Sosyal güvenlik kapsamının il nüfusuna oranı, sosyal güvenlik kapsamındaki aktif çalışanların il nüfusuna oranı, iş yeri sayısı, sosyal güvenlik kapsamındaki bakmakla yükümlü tutulanların il nüfusuna oranı ve sosyal güvenlik kapsamındaki emeklilerin il nüfusuna oranı. Veriler 2016/Kasım ayına ilişkin olup SGK'nın 
resmi internet sitesinden alınmıştır. Etkinlik analizi gerçekleştirilirken MOORA Oran ve MOORA Referans yöntemleri uygulanmaktadır.

Multi-Objective Optimization by Ratio Analysis (MOORA) metodu, ilk olarak Brauers ve Zavadskas (2006) tarafından geliştirilmiş̧ir. Çok amaçlı optimizasyon yöntemi olan MOORA, yeni bir yöntem olup, son y1llarda farklı alanlarda kullanılmaktadır. Karar verme problemlerine destek olmak amacıyla farklı uygulamalar geliştirmede kullanılan bir yöntem olmuştur.

Tablo 2. MOORA Yönteminin Uygulandığı Alanlar

\begin{tabular}{|c|c|}
\hline Uygulama Yapılan Alanlar & Yazarlar \\
\hline Malzeme seçimi & Karande, P., Chakraborty, S. (2012) \\
\hline Personel seçimi & $\begin{array}{l}\text { Baležentis, A., Baležentis, T., } \\
\text { Brauers, W. K. M. (2012) }\end{array}$ \\
\hline $\begin{array}{l}\text { Karar verme modellerinde aralık verilerinin de- } \\
\text { ğerlendirilmesi }\end{array}$ & $\begin{array}{l}\text { Stanujkic, D., Magdalinovic, N., } \\
\text { Stojanovic, S., Jovanovic, R. (2012) }\end{array}$ \\
\hline Üretim sistemlerinde karar verme & Chakraborty, S. (2011) \\
\hline Bölgesel gelişim değerlendirmesi & $\begin{array}{l}\text { Brauers, W. K. M., Ginevičius, R., } \\
\text { Podvezko, V. (2010) }\end{array}$ \\
\hline Yol dizaynı optimizasyonu & $\begin{array}{l}\text { Brauers, W. K. M., Zavadskas, E. K., } \\
\text { Peldschus, F., Turskis, Z. (2008) }\end{array}$ \\
\hline Çok kriterli değerlendirme & Ersöz, F., Atav, A. (2011) \\
\hline Öğütme işleminde parametre optimizasyonu & Gadakh., V. S. (2011) \\
\hline Özelleştirme & $\begin{array}{l}\text { Brauers, W. K. M., } \\
\text { Zavadskas, E. K. (2006) }\end{array}$ \\
\hline
\end{tabular}

MOORA Oran yönteminin ilk adımında, farklı amaçlara karşılık gelen değerlerinden oluşan bir başlangıç matrisi $(X)$ hazırlanır.

MOORA yönteminin aşamaları şu şekildedir:

Aşama 1: Karar matrisi

Başlangıç Matrisinin Oluşturulması: MOORA yönteminin ilk adımında kullanılan Başlangıç Matrisi denklem 1'de gözterildiği gibi oluşturulmaktadır.

$X=\left[\begin{array}{ccccc}x_{11} & \ldots & x_{1 i} & \ldots & x_{1 n} \\ \vdots & \ddots & \vdots & \therefore & \vdots \\ x_{j 1} & \ldots & x_{j i} & \ldots & x_{j n} \\ \vdots & \therefore & \vdots & \ddots & \vdots \\ x_{m 1} & \cdots & x_{m i} & \ldots & x_{m n}\end{array}\right]$

Burada $x_{i j}$ i. alternatifin $\mathrm{j}$. amaçtaki değeridir.

$\dot{\mathrm{I}}=1, \ldots, \mathrm{n}, \mathrm{n}$ alternatif sayıs 
$\mathrm{J}=1, \ldots, \mathrm{m}, \mathrm{m}$ kriter (amaç) sayısı

Aşama 2: Normalizasyon matrisi

Matris Değerlerinin Normalleştirilmesi: Başlangıç matris değerlerinin karesi alınarak toplamları bulunur. Bulunan toplamların karekökü alınarak yöntemin normalleştirme formülüne deklem 2'de gösterildiği gibi hesaplamalar yapılır.

$$
x_{i j}^{\prime}=\frac{x_{i j}}{\sqrt{x_{i j}^{2}}}
$$

$x$ ij' değerleri 0,1 ya da $-1,1$ aralığında olabilir.

Aşama 3: $y_{i j}^{*}$ değerlerinin hesaplanması

xij' değerleri ile oluşturulan normalleştirilmiş matris elde edildikten sonra amaçlar, minimizasyon ve maksimizasyon olarak belirlenir. Belirlenen bu değerler, $y j^{*}$ değerlerini (normalleştirilmiş değerlendirme değerleri) hesaplamak için kullanılır. $y j^{*}$ değerleri hesaplanırken denklem 3'de gösterildiği üzere maksimizasyon değerlerinin toplamından minimizasyon değerlerinin toplamı çıkarılır.

$y_{i j}^{*}=\sum_{i=1}^{i-k} x_{i j}^{\prime}-\sum_{i=k+1}^{i-n} x_{i j}^{\prime}$

$i=1,2, \ldots \ldots \ldots . . . k$ : maksimize edilecek amaçları, $i=k+1, k+2, \ldots n$ : minimize edilecek amaçları göstermektedir. Son aşamada, farklı türden verilerin karşılaştırılabilmesi için karekök veya logaritmik dönüşümler kullanılmaktadır.

\section{Uygulama ve Bulgular}

Çalışmada performans analizi gerçekleştirilirken MOORA oran ve MOORA referans yöntemi kullanılmaktadır. Öncelikle MOORA oran yönteminin aşamaları verilmektedir. Ardından MOORA referans yönteminin sonuçlarıyla karşılaştırılmaktadır.

\subsection{MOORA Oran Yönteminin Uygulama Aşamaları}

İl bazında Sosyal güvenlik kurumlarının performansını ölçmek amacıyla analizde kullanılan değişkenler Tablo 3'te gösterilmektedir. Analiz aşamasında değişkenlerin isimleri kısaltılarak yer almaktadır.

Tablo 3. Analizde Kullanılan Değişkenler ve Kısa Gösterimi

\begin{tabular}{|l|l|}
\hline Sosyal Güvenlik Kapsamının (Gelir Testi Yaptıranlar Hariç) il Nüfusuna Oranı (\%) & max a1 \\
\hline Sosyal Güvenlik Kapsamındaki Aktif Çalışanların İl Nüfusuna Oranı (\%) & max a2 \\
\hline İş yeri sayısı & max a3 \\
\hline Sosyal Güvenlik Kapsamındaki Bakmakla Yükümlü Tutulanların İl Nüfusuna Oranı (\%) & min a4 \\
\hline Sosyal Güvenlik Kapsamındaki Emeklilerin İl Nüfusuna Oranı (\%) & min a5 \\
\hline
\end{tabular}


Tablo 4. Karar Matrisi

\begin{tabular}{|c|c|c|c|c|c|}
\hline & Max a1 & Max a2 & Max a3 & Min a4 & Min a5 \\
\hline Adana & 81,1441 & 21,6446 & 39525 & 45,6041 & 13,8953 \\
\hline Adiyaman & 63,7892 & 15,6931 & 6588 & 40,5411 & 7,55490 \\
\hline Afyonkarahisar & 87,4559 & 22,7636 & 12559 & 49,5637 & 15,1284 \\
\hline Ağr1 & 48,6034 & 9,88523 & 2569 & 35,3344 & 3,38371 \\
\hline Amasya & 87,48365 & 22,97349 & 5697 & 44,32498 & 20,1851 \\
\hline Ankara & 93,07528 & 34,23721 & 135909 & 41,39547 & 17,44259 \\
\hline Antalya & 90,87843 & 29,51549 & 67081 & 47,89176 & 13,47118 \\
\hline Artvin & 81,2875 & 23,79462 & 3710 & 36,50934 & 20,98355 \\
\hline Aydın & 88,6892 & 24,87684 & 25887 & 44,66107 & 19,15129 \\
\hline Balıkesir & 91,10281 & 24,23982 & 27538 & 44,59025 & 22,27275 \\
\hline Bilecik & 87,7327 & 27,94204 & 4558 & 40,57432 & 19,21633 \\
\hline Bingöl & 66,40072 & 17,99996 & 2406 & 42,60326 & 5,797503 \\
\hline Bitlis & 58,23258 & 13,60879 & 2618 & 39,34575 & 5,27803 \\
\hline Bolu & 92,54507 & 29,04756 & 6977 & 44,84724 & 18,65027 \\
\hline Burdur & 88,60841 & 25,76421 & 5786 & 41,76647 & 21,07773 \\
\hline Bursa & 92,26328 & 30,78218 & 72405 & 44,16057 & 17,32052 \\
\hline Çanakkale & 88,80631 & 27,06914 & 13776 & 39,57607 & 22,1611 \\
\hline Çankırı & 83,26454 & 24,01061 & 3039 & 41,00695 & 18,24698 \\
\hline Çorum & 85,93177 & 21,32945 & 8316 & 46,98703 & 17,61529 \\
\hline Denizli & 93,10098 & 29,49392 & 24198 & 44,10768 & 19,49938 \\
\hline Diyarbakır & 65,58865 & 14,23459 & 13830 & 45,73773 & 5,616324 \\
\hline Edirne & 85,94526 & 24,69289 & 9286 & 39,59176 & 21,66062 \\
\hline Elazığ & 81,24811 & 20,26731 & 7338 & 47,46077 & 13,52002 \\
\hline Erzincan & 79,50427 & 23,65264 & 3626 & 40,94525 & 14,90638 \\
\hline Erzurum & 73,87894 & 19,06454 & 9952 & 44,81297 & 10,00143 \\
\hline Eskişehir & 92,25439 & 29,25684 & 19757 & 42,06122 & 20,93633 \\
\hline Gaziantep & 79,03201 & 20,46111 & 31884 & 50,75037 & 7,82054 \\
\hline Giresun & 86,70623 & 21,7619 & 8139 & 44,1016 & 20,84273 \\
\hline Gümüşhane & 72,25884 & 18,69738 & 2327 & 40,6416 & 12,91986 \\
\hline Hakkari & 57,09548 & 16,76047 & 1285 & 36,88492 & 3,450094 \\
\hline Hatay & 78,25774 & 18,50047 & 21692 & 48,69504 & 11,06223 \\
\hline Isparta & 89,00588 & 25,95752 & 8809 & 44,71331 & 18,33505 \\
\hline Mersin & 83,12837 & 23,05937 & 35338 & 46,56274 & 13,50626 \\
\hline İstanbul & 91,65845 & 34,38244 & 498093 & 41,21887 & 16,05714 \\
\hline İzmir & 91,42318 & 29,0871 & 121150 & 41,17123 & 21,16486 \\
\hline Kars & 63,8409 & 16,26734 & 2961 & 40,22339 & 7,350167 \\
\hline Kastamonu & 85,12883 & 22,76583 & 7209 & 43,14033 & 19,22267 \\
\hline Kayseri & 90,82327 & 24,19049 & 29636 & 52,16635 & 14,46644 \\
\hline Kirklareli & 91,38756 & 27,69149 & 7954 & 41,76555 & 21,93052 \\
\hline Kırşehir & 82,24281 & 21,8942 & 3747 & 42,47414 & 17,87446 \\
\hline Malatya & 82,03489 & 22,52686 & 11258 & 46,66723 & 12,84079 \\
\hline Kocaeli & 92,7045 & 33,3099 & 43804 & 44,8709 & 14,5236 \\
\hline Konya & 87,7011 & 23,8690 & 43459 & 50,4402 & 13,3918 \\
\hline
\end{tabular}




\begin{tabular}{|c|c|c|c|c|c|}
\hline Kütahya & 90,7874 & 22,9748 & 10243 & 47,8849 & 19,9276 \\
\hline Manisa & 87,68067 & 26,67995 & 26606 & 44,22169 & 16,77903 \\
\hline Kahramanmaraş & 81,80114 & 19,89677 & 14772 & 53,32201 & 8,582358 \\
\hline Mardin & 61,91435 & 14,02476 & 5247 & 43,31133 & 4,578259 \\
\hline Muğla & 90,21406 & 29,76761 & 32849 & 42,12801 & 18,31843 \\
\hline Muş & 50,30125 & 10,82749 & 2237 & 35,30081 & 4,172946 \\
\hline Nevşehir & 85,44129 & 24,95824 & 5954 & 43,1132 & 17,36985 \\
\hline Niğde & 81,63239 & 22,24441 & 5730 & 46,59971 & 12,78827 \\
\hline Ordu & 81,50577 & 19,56104 & 11941 & 46,20111 & 15,74363 \\
\hline Rize & 88,02276 & 26,75125 & 6457 & 40,62429 & 20,64721 \\
\hline Sakarya & 89,0668 & 27,25117 & 22094 & 45,57464 & 16,24099 \\
\hline Samsun & 85,55376 & 22,18264 & 24060 & 45,11236 & 18,25876 \\
\hline Siirt & 60,90969 & 13,84731 & 2185 & 41,712 & 5,350381 \\
\hline Sinop & 83,49255 & 21,6888 & 3977 & 37,26632 & 24,53743 \\
\hline Sivas & 85,59512 & 22,07359 & 9617 & 46,68397 & 16,83756 \\
\hline Tekirdağ & 91,87597 & 34,59458 & 22902 & 41,71721 & 15,56418 \\
\hline Tokat & 83,06171 & 18,70705 & 8132 & 48,93437 & 15,42029 \\
\hline Trabzon & 87,88076 & 24,88349 & 17080 & 44,43104 & 18,56622 \\
\hline Tunceli & 70,74572 & 24,63637 & 1218 & 34,74962 & 11,35973 \\
\hline Şanlıurfa & 62,04672 & 12,24587 & 12003 & 46,4019 & 3,398949 \\
\hline Uşak & 89,30668 & 28,48111 & 8328 & 40,45355 & 20,37202 \\
\hline Van & 65,19805 & 12,42004 & 7985 & 48,77179 & 4,006213 \\
\hline Yozgat & 79,36256 & 19,89939 & 5741 & 43,57031 & 15,89286 \\
\hline Zonguldak & 88,87206 & 21,19223 & 10885 & 41,69339 & 25,98644 \\
\hline Aksaray & 80,48193 & 22,50009 & 6753 & 46,48549 & 11,49635 \\
\hline Bayburt & 71,1701 & 20,78676 & 1110 & 36,88111 & 13,50223 \\
\hline Karaman & 88,28553 & 27,95917 & 4298 & 45,04452 & 15,28184 \\
\hline Kırıkkale & 89,596 & 24,52871 & 4721 & 46,86815 & 18,19914 \\
\hline Batman & 64,34767 & 14,23214 & 3798 & 44,52302 & 5,592509 \\
\hline Şırnak & 53,8159 & 13,58592 & 2133 & 37,56996 & 2,660022 \\
\hline Bartın & 91,18437 & 22,73056 & 4079 & 44,35885 & 24,09495 \\
\hline Ardahan & 67,45881 & 19,99698 & 1206 & 39,0903 & 8,371531 \\
\hline Iğdır & 55,9328 & 14,54153 & 1768 & 35,52954 & 5,86172 \\
\hline Yalova & 89,29213 & 31,48076 & 6729 & 38,97261 & 18,83876 \\
\hline Karabük & 92,23988 & 25,26817 & 5180 & 45,25704 & 21,71467 \\
\hline Kilis & 72,65103 & 20,62531 & 1553 & 42,42792 & 9,597796 \\
\hline Osmaniye & 77,88749 & 17,96722 & 6404 & 49,26988 & 10,65039 \\
\hline Düzce & 86,56426 & 27,05639 & 7618 & 43,97211 & 15,53576 \\
\hline
\end{tabular}

Tablo 4'te analize konu olan değişkenlere ilişkin kullanılan veriler yer almaktadır. Toplam 81 ilin verileri üç çıktı ve iki girdi değişkeni kullanılmıştır. 
Tablo 5. Normalizasyon Matrisi

\begin{tabular}{|c|c|c|c|c|c|}
\hline & Max a1 & Max a2 & Max a3 & Min a4 & Min a5 \\
\hline Adana & 0,110593 & 0,103104 & 0,071097 & 0,116165 & 0,097876 \\
\hline Adıyaman & 0,086939 & 0,074754 & 0,01185 & 0,103268 & 0,053215 \\
\hline Afyonkarahisar & 0,119195 & 0,108434 & 0,022591 & 0,126251 & 0,106562 \\
\hline Ağr1 & 0,066242 & 0,047088 & 0,004621 & 0,090005 & 0,023834 \\
\hline Amasya & 0,119233 & 0,109434 & 0,010248 & 0,112906 & 0,142181 \\
\hline Ankara & 0,126854 & 0,163088 & 0,24447 & 0,105444 & 0,122862 \\
\hline Antalya & 0,12386 & 0,140596 & 0,120664 & 0,121992 & 0,094888 \\
\hline Artvin & 0,110788 & 0,113345 & 0,006673 & 0,092998 & 0,147804 \\
\hline Aydın & 0,120876 & 0,1185 & 0,046565 & 0,113762 & 0,134898 \\
\hline Balıkesir & 0,124165 & 0,115466 & 0,049535 & 0,113582 & 0,156885 \\
\hline Bilecik & 0,119572 & 0,133101 & 0,008199 & 0,103353 & 0,135356 \\
\hline Bingöl & 0,090498 & 0,085742 & 0,004328 & 0,108521 & 0,040837 \\
\hline Bitlis & 0,079366 & 0,064825 & 0,004709 & 0,100223 & 0,037177 \\
\hline Bolu & 0,126131 & 0,138367 & 0,01255 & 0,114237 & 0,131369 \\
\hline Burdur & 0,120766 & 0,122727 & 0,010408 & 0,106389 & 0,148468 \\
\hline Bursa & 0,125747 & 0,14663 & 0,13024 & 0,112488 & 0,122002 \\
\hline Çanakkale & 0,121035 & 0,128943 & 0,02478 & 0,10081 & 0,156099 \\
\hline Çankırı & 0,113482 & 0,114374 & 0,005466 & 0,104455 & 0,128528 \\
\hline Çorum & 0,117118 & 0,101602 & 0,014959 & 0,119687 & 0,124079 \\
\hline Denizli & 0,126889 & 0,140493 & 0,043527 & 0,112353 & 0,13735 \\
\hline Diyarbakır & 0,089392 & 0,067806 & 0,024877 & 0,116505 & 0,03956 \\
\hline Edirne & 0,117136 & 0,117624 & 0,016703 & 0,10085 & 0,152573 \\
\hline Elazı̆g & 0,110734 & 0,096543 & 0,013199 & 0,120894 & 0,095232 \\
\hline Erzincan & 0,108358 & 0,112669 & 0,006522 & 0,104297 & 0,104998 \\
\hline Erzurum & 0,100691 & 0,090813 & 0,017901 & 0,114149 & 0,070448 \\
\hline Eskişehir & 0,125735 & 0,139364 & 0,035538 & 0,10714 & 0,147472 \\
\hline Gaziantep & 0,107714 & 0,097466 & 0,057352 & 0,129273 & 0,055086 \\
\hline Giresun & 0,118173 & 0,103662 & 0,01464 & 0,112337 & 0,146812 \\
\hline Gümüşhane & 0,098483 & 0,089064 & 0,004186 & 0,103524 & 0,091005 \\
\hline Hakkari & 0,077816 & 0,079838 & 0,002311 & 0,093955 & 0,024302 \\
\hline Hatay & 0,106659 & 0,088126 & 0,039019 & 0,124038 & 0,07792 \\
\hline Isparta & 0,121307 & 0,123648 & 0,015845 & 0,113896 & 0,129149 \\
\hline Mersin & 0,113297 & 0,109843 & 0,063565 & 0,118606 & 0,095135 \\
\hline İstanbul & 0,124923 & 0,16378 & 0,895958 & 0,104994 & 0,113103 \\
\hline İzmir & 0,124602 & 0,138556 & 0,217922 & 0,104873 & 0,149081 \\
\hline Kars & 0,08701 & 0,077489 & 0,005326 & 0,102459 & 0,051773 \\
\hline Kastamonu & 0,116023 & 0,108444 & 0,012967 & 0,109889 & 0,135401 \\
\hline Kayseri & 0,123784 & 0,115231 & 0,053309 & 0,13288 & 0,101899 \\
\hline Kırklareli & 0,124553 & 0,131908 & 0,014307 & 0,106387 & 0,154474 \\
\hline Kırşehir & 0,11209 & 0,104292 & 0,00674 & 0,108192 & 0,125904 \\
\hline Malatya & 0,111807 & 0,107306 & 0,020251 & 0,118873 & 0,090448 \\
\hline Kocaeli & 0,126348 & 0,158671 & 0,078794 & 0,114297 & 0,102302 \\
\hline
\end{tabular}




\begin{tabular}{|c|c|c|c|c|c|}
\hline Konya & 0,119529 & 0,1137 & 0,078173 & 0,128483 & 0,09433 \\
\hline Kütahya & 0,123736 & 0,10944 & 0,018425 & 0,121975 & 0,140366 \\
\hline Manisa & 0,119501 & 0,127089 & 0,047858 & 0,112643 & 0,118188 \\
\hline Kahramanmaraş & 0,111488 & 0,094778 & 0,026572 & 0,135824 & 0,060452 \\
\hline Mardin & 0,084384 & 0,066807 & 0,009438 & 0,110324 & 0,032248 \\
\hline Muğla & 0,122954 & 0,141797 & 0,059088 & 0,10731 & 0,129032 \\
\hline Muş & 0,068556 & 0,051576 & 0,004024 & 0,08992 & 0,029393 \\
\hline Nevşehir & 0,116449 & 0,118888 & 0,01071 & 0,10982 & 0,12235 \\
\hline Niğde & 0,111258 & 0,105961 & 0,010307 & 0,118701 & 0,090078 \\
\hline Ordu & 0,111085 & 0,093178 & 0,021479 & 0,117685 & 0,110895 \\
\hline Rize & 0,119967 & 0,127429 & 0,011615 & 0,10348 & 0,145435 \\
\hline Sakarya & 0,12139 & 0,12981 & 0,039742 & 0,11609 & 0,114398 \\
\hline Samsun & 0,116602 & 0,105666 & 0,043279 & 0,114912 & 0,128611 \\
\hline Siirt & 0,083015 & 0,065961 & 0,00393 & 0,10625 & 0,037687 \\
\hline Sinop & 0,113793 & 0,103314 & 0,007154 & 0,094926 & 0,172837 \\
\hline Sivas & 0,116659 & 0,105147 & 0,017299 & 0,118915 & 0,118601 \\
\hline Tekirdağ & 0,125219 & 0,16479 & 0,041196 & 0,106264 & 0,109631 \\
\hline Tokat & 0,113206 & 0,089111 & 0,014628 & 0,124648 & 0,108618 \\
\hline Trabzon & 0,119774 & 0,118532 & 0,030723 & 0,113177 & 0,130777 \\
\hline Tunceli & 0,09642 & 0,117355 & 0,002191 & 0,088516 & 0,080016 \\
\hline Şanliurfa & 0,084564 & 0,058333 & 0,021591 & 0,118197 & 0,023942 \\
\hline Uşak & 0,121717 & 0,135669 & 0,01498 & 0,103045 & 0,143497 \\
\hline Van & 0,088859 & 0,059163 & 0,014363 & 0,124233 & 0,028219 \\
\hline Yozgat & 0,108164 & 0,09479 & 0,010327 & 0,110984 & 0,111946 \\
\hline Zonguldak & 0,121125 & 0,100949 & 0,01958 & 0,106203 & 0,183043 \\
\hline Aksaray & 0,10969 & 0,107179 & 0,012147 & 0,11841 & 0,080978 \\
\hline Bayburt & 0,096999 & 0,099017 & 0,001997 & 0,093945 & 0,095107 \\
\hline Karaman & 0,120326 & 0,133183 & 0,007731 & 0,114739 & 0,107642 \\
\hline Kırıkkale & 0,122112 & 0,116842 & 0,008492 & 0,119384 & 0,128191 \\
\hline Batman & 0,0877 & 0,067794 & 0,006832 & 0,113411 & 0,039393 \\
\hline Şırnak & 0,073346 & 0,064716 & 0,003837 & 0,0957 & 0,018737 \\
\hline Bartın & 0,124276 & 0,108276 & 0,007337 & 0,112993 & 0,16972 \\
\hline Ardahan & 0,091941 & 0,095255 & 0,002169 & 0,099572 & 0,058967 \\
\hline Iğdır & 0,076232 & 0,069268 & 0,00318 & 0,090502 & 0,041289 \\
\hline Yalova & 0,121698 & 0,149958 & 0,012104 & 0,099273 & 0,132697 \\
\hline Karabük & 0,125715 & 0,120364 & 0,009318 & 0,115281 & 0,152954 \\
\hline Kilis & 0,099017 & 0,098248 & 0,002794 & 0,108074 & 0,067605 \\
\hline Osmaniye & 0,106154 & 0,085586 & 0,011519 & 0,125502 & 0,075019 \\
\hline Düzce & 0,11798 & 0,128882 & 0,013703 & 0,112008 & 0,109431 \\
\hline
\end{tabular}

Tablo 5'te normalizasyon matrisi yer almaktadır. Normalizasyon matrisi oluşturulurken her bir alternatif için verilen kriterlerin karesi alınmaktadır. Karesi alınan kriterlerin toplamı alınarak karekökleri hesaplanmaktadır. Sonrasında karar matrisinde yer alan orijinal değerlerden hareketle, her bir değer öncesinde hesaplanan kareköklerine bölünerek elde edilmektedir. 
Tablo 6. $y_{i j}^{*}$ Değerleri

\begin{tabular}{|c|c|c|c|c|c|}
\hline & $Y_{i j}$ & & $Y_{i j}$ & & $Y_{i j}$ \\
\hline Adana & 0,070752 & Giresun & $-0,02267$ & Samsun & 0,022024 \\
\hline Adiyaman & 0,01706 & Gümüşhane & $-0,0028$ & Siirt & 0,008969 \\
\hline Afyonkarahisar & 0,017407 & Hakkari & 0,041709 & Sinop & $-0,0435$ \\
\hline Ağn1 & 0,004112 & Hatay & 0,031846 & Sivas & 0,001589 \\
\hline Amasya & $-0,01617$ & Isparta & 0,017757 & Tekirdağ & 0,11531 \\
\hline Ankara & 0,306105 & Mersin & 0,072963 & Tokat & $-0,01632$ \\
\hline Antalya & 0,168239 & İstanbul & 0,966563 & Trabzon & 0,025075 \\
\hline Artvin & $-0,01$ & İzmir & 0,227125 & Tunceli & 0,047435 \\
\hline Aydın & 0,03728 & Kars & 0,015593 & Şanlıurfa & 0,02235 \\
\hline Balıkesir & 0,018699 & Kastamonu & $-0,00785$ & Uşak & 0,025825 \\
\hline Bilecik & 0,022163 & Kayseri & 0,057545 & Van & 0,009933 \\
\hline Bingöl & 0,031211 & Kırklareli & 0,009907 & Yozgat & $-0,00965$ \\
\hline Bitlis & 0,0115 & Kırşehir & $-0,01097$ & Zonguldak & $-0,04759$ \\
\hline Bolu & 0,031443 & Kocaeli & 0,147214 & Aksaray & 0,029628 \\
\hline Burdur & $-0,00096$ & Konya & 0,088589 & Bayburt & 0,00896 \\
\hline Bursa & 0,168127 & Kütahya & $-0,01074$ & Karaman & 0,038858 \\
\hline Çanakkale & 0,01785 & Malatya & 0,030042 & Kırıkkale & $-0,00013$ \\
\hline Çankırı & 0,00034 & Manisa & 0,063617 & Batman & 0,009523 \\
\hline Çorum & $-0,01009$ & Kahramanmaraş & 0,036561 & Şırnak & 0,027463 \\
\hline Denizli & 0,061206 & Mardin & 0,018056 & Bartın & $-0,04282$ \\
\hline Diyarbakır & 0,02601 & Muğla & 0,087498 & Ardahan & 0,030825 \\
\hline Edirne & $-0,00196$ & Muş & 0,004844 & Iğdır & 0,016889 \\
\hline Elazı̆g & 0,00435 & Nevşehir & 0,013877 & Yalova & 0,05179 \\
\hline Erzincan & 0,018254 & Niğde & 0,018747 & Karabük & $-0,01284$ \\
\hline Erzurum & 0,024808 & Ordu & $-0,00284$ & Kilis & 0,02438 \\
\hline Eskişehir & 0,046026 & Rize & 0,010096 & Osmaniye & 0,002738 \\
\hline Gaziantep & 0,078172 & Sakarya & 0,060455 & Düzce & 0,039127 \\
\hline
\end{tabular}

Tablo 6'da $Y_{i j}$ değerleri hesaplanmaktadır. $Y_{i j}$ değerleri hesaplanırken normalizasyon matrisinden hareketle, her bir alternatif için oluşturulan kriterlerden maksimum olanların toplamı minimum olanların toplamından çıkartılmaktadır. Böylece her alternatif için bir $Y_{i j}$ değeri bulunmaktadır.

Tablo 7. $y_{i j}$ Etkinlik Skorlarının Büyükten Küçüğe Doğru Sıralanması

\begin{tabular}{|c|c|c|c|c|c|c|c|c|}
\hline İller & $\begin{array}{c}\text { Yij } \\
\text { Etkinlik } \\
\text { Sıralaması }\end{array}$ & $\begin{array}{c}\text { Sirala } \\
\text { ma }\end{array}$ & İller & $\begin{array}{c}\text { Yij } \\
\text { Etkinlik } \\
\text { Siralaması }\end{array}$ & $\begin{array}{c}\text { Sirala } \\
\text { ma }\end{array}$ & Iller & $\begin{array}{c}\text { Yij Etkinlik } \\
\text { Siralamas1 }\end{array}$ & $\begin{array}{c}\text { Sirala } \\
\text { ma }\end{array}$ \\
\hline İstanbul & 0,966563 & 1 & Ardahan & 0,030825 & 28 & Batman & 0,009523 & 55 \\
\hline Ankara & 0,306105 & 2 & Malatya & 0,030042 & 29 & Siirt & 0,008969 & 56 \\
\hline İzmir & 0,227125 & 3 & Aksaray & 0,029628 & 30 & Bayburt & 0,00896 & 57 \\
\hline Antalya & 0,168239 & 4 & Şırnak & 0,027463 & 31 & Muş & 0,004844 & 58 \\
\hline Bursa & 0,168127 & 5 & Diyarbakır & 0,02601 & 32 & Elazı̆ & 0,00435 & 59 \\
\hline Kocaeli & 0,147214 & 6 & Uşak & 0,025825 & 33 & Ağrı & 0,004112 & 60 \\
\hline Tekirdağ & 0,11531 & 7 & Trabzon & 0,025075 & 34 & Osmaniye & 0,002738 & 61 \\
\hline Konya & 0,088589 & 8 & Erzurum & 0,024808 & 35 & Sivas & 0,001589 & 62 \\
\hline
\end{tabular}




\begin{tabular}{|c|c|c|c|c|c|c|c|c|}
\hline Muğla & 0,087498 & 9 & Kilis & 0,02438 & 36 & Cankırı & 0,00034 & 63 \\
\hline Gaziantep & 0,078172 & 10 & Sanlıurfa & 0,02235 & 37 & Kırıkkale & $-0,00013$ & 64 \\
\hline Mersin & 0,072963 & 11 & Bilecik & 0,022163 & 38 & Burdur & $-0,00096$ & 65 \\
\hline Adana & 0,070752 & 12 & Samsun & 0,022024 & 39 & Edirne & $-0,00196$ & 66 \\
\hline Manisa & 0,063617 & 13 & Niğde & 0,018747 & 40 & Gümüşhane & $-0,0028$ & 67 \\
\hline Denizli & 0,061206 & 14 & Balıkesir & 0,018699 & 41 & Ordu & $-0,00284$ & 68 \\
\hline Sakarya & 0,060455 & 15 & Erzincan & 0,018254 & 42 & Kastamonu & $-0,00785$ & 69 \\
\hline Kayseri & 0,057545 & 16 & Mardin & 0,018056 & 43 & Yozgat & $-0,00965$ & 70 \\
\hline Yalova & 0,05179 & 17 & Çanakkale & 0,01785 & 44 & Artvin & $-0,01$ & 71 \\
\hline Tunceli & 0,047435 & 18 & Isparta & 0,017757 & 45 & Çorum & $-0,01009$ & 72 \\
\hline Eskişehir & 0,046026 & 19 & Afyon & 0,017407 & 46 & Kütahya & $-0,01074$ & 73 \\
\hline Hakkari & 0,041709 & 20 & Adıyaman & 0,01706 & 47 & Kırşehir & $-0,01097$ & 74 \\
\hline Düzce & 0,039127 & 21 & Iğdır & 0,016889 & 48 & Karabük & $-0,01284$ & 75 \\
\hline Karaman & 0,038858 & 22 & Kars & 0,015593 & 49 & Amasya & $-0,01617$ & 76 \\
\hline Aydın & 0,03728 & 23 & Nevşehir & 0,013877 & 50 & Tokat & $-0,01632$ & 77 \\
\hline K.Maraş & 0,036561 & 24 & Bitlis & 0,0115 & 51 & Giresun & $-0,02267$ & 78 \\
\hline Hatay & 0,031846 & 25 & Rize & 0,010096 & 52 & Bartın & $-0,04282$ & 79 \\
\hline Bolu & 0,031443 & 26 & Van & 0,009933 & 53 & Sinop & $-0,0435$ & 80 \\
\hline Bingöl & 0,031211 & 27 & Kırklareli & 0,009907 & 54 & Zonguldak & $-0,04759$ & 81 \\
\hline
\end{tabular}

Tablo 7'de bulunan $Y_{i j}$ değerlerinin büyükten küçüğe doğru sıralanmasıyla her alternatif için performans siralaması elde edilmektedir. MOORA oran metoduna göre yapılan analizde ilk beşte sırasıyla, İstanbul, Ankara, İzmir, Antalya ve Bursa illeri yer almaktadır. Genellikle nüfusun en fazla olduğu iller etkinlik siralamasında ilk siralarda yer aldığ sonucuna varılmaktadir.

\subsection{MOORA Referans Noktası Yaklaşımı Uygulama Aşamaları}

MOORA Oran yöntemi ile bu yöntemin ilk iki aşaması aynıdır. Bu yöntemde MOORA oran yaklaşımında elde edilen normalizasyon matrisinden hareketle $r_{j}$ değerleri hesaplanmaktadır. $r_{j}$ : maksimum değişkenler iç̧in Karar Verme Birimlerinden (KVB) maksimum olanı, minimum değişkenler için KVB'nin minimumu seçilmektedir.

Aşama 3 (MOORA Referans):

$$
\begin{array}{cccccc} 
& \max \text { a1 } & \max \text { a2 } & \max \text { a3 } & \min \text { a4 } & \min \mathrm{a} 5 \\
r_{j}\left(r_{j}-x_{i j}^{*}\right. & 0,126889 & 0,16479 & 0,895958 & 0,088516 & 0,018737
\end{array}
$$

Elde edilen $r_{j}$ değerleri $x_{i j}^{*}$ değerlerinden çıkartılmaktadır. Böylelikle her bir KVB'nin maksimum değere olan uzaklığı tespit edilmektedir. Minimum değişkenler için ise KVB'lerinden minimum olanı seçilerek uzaklık tespit edilmektedir. Maksimum değişkenler için uzaklık tespit edilirken mutlak değer kullanılmaktadır. Bu yapılan işlemler sonrasında oluşan matriste satır elemanlarının maksimum değerleri alınarak $y_{i j}^{*}$ elde edilmektedir. $y_{i j}^{*}$ 'nin küçükten büyüğe doğru sıralanması da etkinlik sıralamasını oluşturmaktadır. 
Tablo 8. MOORA- Referans Noktası Yaklaşımı Analizine İlişkin Performans Değerleri ve Sıralaması

\begin{tabular}{|c|c|c|c|c|c|c|c|c|}
\hline İller & $\max a 1$ & $\max a 2$ & $\max a 3$ & $\min \mathrm{a} 4$ & $\min$ a5 & $\begin{array}{c}\text { Yij } \\
\text { MOORA referans }\end{array}$ & $\begin{array}{l}\text { Siralama } \\
\text { (M-R) }\end{array}$ & $\begin{array}{c}\text { Siralama } \\
(\mathrm{M}-\mathrm{O})\end{array}$ \\
\hline İstanbul & 0,001966 & 0,001011 & 0 & 0,016479 & 0,094367 & 0,094366754 & 1 & 1 \\
\hline Ankara & $3,5 \mathrm{E}-05$ & 0,001702 & 0,651488 & 0,016929 & 0,104126 & 0,651488217 & 2 & 2 \\
\hline İzmir & 0,002287 & 0,026235 & 0,678036 & 0,016357 & 0,130345 & 0,678036366 & 3 & 3 \\
\hline Bursa & 0,001142 & 0,01816 & 0,765718 & 0,023972 & 0,103266 & 0,765717747 & 4 & 5 \\
\hline Antalya & 0,003029 & 0,024194 & 0,775294 & 0,033476 & 0,076152 & 0,775294435 & 5 & 4 \\
\hline Kocaeli & 0,00054 & 0,006119 & 0,817165 & 0,025781 & 0,083565 & 0,817164565 & 6 & 6 \\
\hline Konya & 0,007359 & 0,051091 & 0,817785 & 0,039968 & 0,075593 & 0,817785143 & 7 & 8 \\
\hline Adana & 0,016296 & 0,061687 & 0,824862 & 0,027649 & 0,07914 & 0,824861531 & 8 & 12 \\
\hline Mersin & 0,013592 & 0,054948 & 0,832393 & 0,030091 & 0,076399 & 0,83239301 & 9 & 11 \\
\hline Muğla & 0,003935 & 0,022993 & 0,83687 & 0,018795 & 0,110295 & 0,836870166 & 10 & 9 \\
\hline Gaziantep & 0,019175 & 0,067324 & 0,838606 & 0,040758 & 0,03635 & 0,838605986 & 11 & 10 \\
\hline Kayseri & 0,003104 & 0,04956 & 0,84265 & 0,044365 & 0,083162 & 0,842649636 & 12 & 16 \\
\hline Balıkesir & 0,002723 & 0,049325 & 0,846423 & 0,025066 & 0,138148 & 0,84642347 & 13 & 41 \\
\hline Manisa & 0,007387 & 0,037701 & 0,8481 & 0,024128 & 0,099452 & 0,84809993 & 14 & 13 \\
\hline Aydın & 0,006013 & 0,04629 & 0,849393 & 0,025247 & 0,116161 & 0,849393251 & 15 & 23 \\
\hline Denizli & 0 & 0,024297 & 0,852431 & 0,023837 & 0,118613 & 0,852431385 & 16 & 14 \\
\hline Samsun & 0,010286 & 0,059124 & 0,85268 & 0,026396 & 0,109875 & 0,852679616 & 17 & 39 \\
\hline Tekirdağ & 0,00167 & 0 & 0,854763 & 0,017748 & 0,090894 & 0,8547626 & 18 & 7 \\
\hline Sakarya & 0,005498 & 0,03498 & 0,856216 & 0,027574 & 0,095662 & 0,856216012 & 19 & 15 \\
\hline Hatay & 0,02023 & 0,076664 & 0,856939 & 0,035522 & 0,059184 & 0,85693912 & 20 & 25 \\
\hline Eskişehir & 0,001154 & 0,025426 & 0,86042 & 0,018624 & 0,128735 & 0,860419753 & 21 & 19 \\
\hline Trabzon & 0,007115 & 0,046258 & 0,865235 & 0,024661 & 0,11204 & 0,865235079 & 22 & 34 \\
\hline Kahramanmaraş & 0,015401 & 0,070013 & 0,869387 & 0,047308 & 0,041716 & 0,869386656 & 23 & 24 \\
\hline Diyarbakır & 0,037497 & 0,096984 & 0,871081 & 0,027989 & 0,020824 & 0,871081104 & 24 & 32 \\
\hline Çanakkale & 0,005853 & 0,035847 & 0,871178 & 0,012294 & 0,137362 & 0,871178238 & 25 & 44 \\
\hline Afyonkarahisar & 0,007694 & 0,056356 & 0,873367 & 0,037735 & 0,087825 & 0,87336735 & 26 & 46 \\
\hline Şanlıurfa & 0,042324 & 0,106457 & 0,874367 & 0,029681 & 0,005205 & 0,87436747 & 27 & 37 \\
\hline Ordu & 0,015803 & 0,071612 & 0,874479 & 0,02917 & 0,092158 & 0,874478994 & 28 & 68 \\
\hline Malatya & 0,015082 & 0,057484 & 0,875708 & 0,030357 & 0,071711 & 0,875707558 & 29 & 29 \\
\hline Zonguldak & 0,005764 & 0,063842 & 0,876379 & 0,017687 & 0,164307 & 0,876378502 & 30 & 81 \\
\hline Kütahya & 0,003153 & 0,05535 & 0,877533 & 0,033459 & 0,12163 & 0,877533317 & 31 & 73 \\
\hline Erzurum & 0,026198 & 0,073977 & 0,878057 & 0,025634 & 0,051711 & 0,878056761 & 32 & 35 \\
\hline Sivas & 0,01023 & 0,059643 & 0,878659 & 0,0304 & 0,099864 & 0,878659351 & 33 & 62 \\
\hline Edirne & 0,009753 & 0,047166 & 0,879255 & 0,012334 & 0,133837 & 0,879254746 & 34 & 66 \\
\hline Isparta & 0,005581 & 0,041142 & 0,880113 & 0,02538 & 0,110412 & 0,880112763 & 35 & 45 \\
\hline Uşak & 0,005171 & 0,029121 & 0,880978 & 0,014529 & 0,12476 & 0,880977975 & 36 & 33 \\
\hline Çorum & 0,009771 & 0,063188 & 0,881 & 0,031172 & 0,105342 & 0,88099956 & 37 & 72 \\
\hline Giresun & 0,008715 & 0,061128 & 0,881318 & 0,023822 & 0,128076 & 0,881317944 & 38 & 78 \\
\hline Tokat & 0,013683 & 0,07568 & 0,881331 & 0,036132 & 0,089881 & 0,881330535 & 39 & 77 \\
\hline Van & 0,038029 & 0,105628 & 0,881595 & 0,035718 & 0,009482 & 0,881594955 & 40 & 53 \\
\hline Kırklareli & 0,002335 & 0,032883 & 0,881651 & 0,017871 & 0,135738 & 0,881650717 & 41 & 54 \\
\hline Düzce & 0,008909 & 0,035908 & 0,882255 & 0,023492 & 0,090694 & 0,882255106 & 42 & 21 \\
\hline Elazı̆g & 0,016154 & 0,068248 & 0,882759 & 0,032378 & 0,076496 & 0,882758764 & 43 & 59 \\
\hline Kastamonu & 0,010865 & 0,056346 & 0,882991 & 0,021373 & 0,116664 & 0,882990806 & 44 & 69 \\
\hline Bolu & 0,000758 & 0,026423 & 0,883408 & 0,025721 & 0,112632 & 0,883408122 & 45 & 26 \\
\hline Aksaray & 0,017199 & 0,057612 & 0,883811 & 0,029894 & 0,062241 & 0,883811048 & 46 & 30 \\
\hline Yalova & 0,005191 & 0,014833 & 0,883854 & 0,010757 & 0,11396 & 0,883854219 & 47 & 17 \\
\hline Adiyaman & 0,039949 & 0,090037 & 0,884108 & 0,014753 & 0,034479 & 0,884107847 & 48 & 47 \\
\hline Rize & 0,006921 & 0,037361 & 0,884343 & 0,014964 & 0,126698 & 0,884343486 & 49 & 52 \\
\hline Osmaniye & 0,020735 & 0,079204 & 0,884439 & 0,036987 & 0,056283 & 0,884438822 & 50 & 61 \\
\hline Nevşehir & 0,010439 & 0,045902 & 0,885248 & 0,021304 & 0,103613 & 0,885248271 & 51 & 50 \\
\hline Burdur & 0,006123 & 0,042063 & 0,88555 & 0,017874 & 0,129731 & 0,885550466 & 52 & 65 \\
\hline Yozgat & 0,018724 & 0,07 & 0,885631 & 0,022468 & 0,09321 & 0,885631411 & 53 & 70 \\
\hline Niğde & 0,015631 & 0,05883 & 0,885651 & 0,030185 & 0,071341 & 0,885651197 & 54 & 40 \\
\hline Amasya & 0,007656 & 0,055357 & 0,885711 & 0,024391 & 0,123444 & 0,885710557 & 55 & 76 \\
\hline Mardin & 0,042505 & 0,097984 & 0,88652 & 0,021809 & 0,013512 & 0,886520006 & 56 & 43 \\
\hline Karabük & 0,001174 & 0,044426 & 0,886641 & 0,026765 & 0,134217 & 0,886640524 & 57 & 75 \\
\hline Kırıkkale & 0,004777 & 0,047948 & 0,887466 & 0,030869 & 0,109455 & 0,887466163 & 58 & 64 \\
\hline Bilecik & 0,007317 & 0,031689 & 0,887759 & 0,014837 & 0,11662 & 0,887759364 & 59 & 38 \\
\hline Karaman & 0,006563 & 0,031608 & 0,888227 & 0,026224 & 0,088906 & 0,888227046 & 60 & 22 \\
\hline Bartın & 0,002612 & 0,056514 & 0,888621 & 0,024477 & 0,150984 & 0,888620978 & 61 & 79 \\
\hline
\end{tabular}




\begin{tabular}{|l|c|c|c|c|c|c|c|c|}
\hline Sinop & 0,013095 & 0,061476 & 0,888804 & 0,006411 & 0,1541 & 0,888804453 & 62 & 80 \\
\hline Batman & 0,039188 & 0,096996 & 0,889126 & 0,024895 & 0,020656 & 0,889126434 & 63 & 55 \\
\hline Kırşehir & 0,014799 & 0,060498 & 0,889218 & 0,019676 & 0,107168 & 0,889218172 & 64 & 74 \\
\hline Artvin & 0,016101 & 0,051445 & 0,889285 & 0,004482 & 0,129067 & 0,889284727 & 65 & 71 \\
\hline Erzincan & 0,018531 & 0,052122 & 0,889436 & 0,015782 & 0,086261 & 0,889435824 & 66 & 42 \\
\hline Çankırı & 0,013406 & 0,050416 & 0,890492 & 0,015939 & 0,109792 & 0,890491706 & 67 & 63 \\
\hline Kars & 0,039879 & 0,087301 & 0,890632 & 0,013943 & 0,033036 & 0,89063201 & 68 \\
\hline Bitlis & 0,047523 & 0,099965 & 0,891249 & 0,011707 & 0,018441 & 0,891248991 & 69 \\
\hline Ağrı & 0,060646 & 0,117702 & 0,891337 & 0,00149 & 0,005098 & 0,891337131 & 70 & 61 \\
\hline Bingöl & 0,03639 & 0,079048 & 0,89163 & 0,020005 & 0,0221 & 0,891630332 & 71 & 27 \\
\hline Gümüşhane & 0,028406 & 0,075726 & 0,891772 & 0,015008 & 0,072268 & 0,891772435 & 72 & 67 \\
\hline Muş & 0,058332 & 0,113214 & 0,891934 & 0,001404 & 0,010657 & 0,891934325 & 73 & 58 \\
\hline Siirt & 0,043874 & 0,098829 & 0,892028 & 0,017735 & 0,01895 & 0,892027861 & 74 & 56 \\
\hline Şırnak & 0,053542 & 0,100074 & 0,892121 & 0,007184 & 0 & 0,892121398 & 75 \\
\hline Ĭgdır & 0,050657 & 0,095522 & 0,892778 & 0,001987 & 0,022552 & 0,892777951 & 76 \\
\hline Kilis & 0,027872 & 0,066542 & 0,893165 & 0,019558 & 0,048868 & 0,893164688 & 77 & 36 \\
\hline Hakkari & 0,049072 & 0,084952 & 0,893647 & 0,005439 & 0,005565 & 0,893646761 & 78 & 20 \\
\hline Tunceli & 0,030468 & 0,047436 & 0,893767 & 0 & 0,061279 & 0,893767279 & 79 & 18 \\
\hline Ardahan & 0,034948 & 0,069535 & 0,893789 & 0,011057 & 0,040231 & 0,893788864 & 80 \\
\hline Bayburt & 0,02989 & 0,065773 & 0,893962 & 0,005429 & 0,07637 & 0,893961547 & 81 \\
\hline
\end{tabular}

Tablo 8'de MOORA Referans ve MOORA Oran yöntemine göre etkinlik sonuçları ve illerin sıralaması yer almaktadır. Elde edilen bulgulara göre, MOORA Oran yöntemine ilişkin etkinlik sıralamasında yer alan ilk beş ilin sıralaması, İstanbul, Ankara, İzmir, Antalya ve Bursa'dır. MOORA Referans yöntemine göre ise, İstanbul, Ankara, İzmir, Bursa ve Antalya'dır. İki yöntemde de ilk beşte yer alan iller genellikle aynı olmakla beraber sadece son iki ilin yerleri değişiktir. Bu şehirlerin ilk sıralarda yer almasının nedenleri olarak, büyük şehir olmaları, ekonomik ve turizm potansiyeli bakımından iş yeri sayısının fazla olması, istihdam olanaklarının diğer şehirlere göre daha fazla olması ve nüfus bakımından en kalabalık şehir olmaları sayılabilir. Her iki yöntemde de etkinlik sıralamasında yer alan son illere bakıldığında farklılıklar gözlemlenmektedir. Son sıralarda yer alan illerin verileri arasında çok önemli bir fark olmaması ve yöntemlerin farklı hesaplamaları olması bu farklılı̆̆ın nedenleri arasında sayılabilir.

\section{Sonuç}

Özellikle sanayileşme ile birlikte gelişen sosyal güvenlik sistemleri, günümüzde çok önemli bir konuma evrilmiştir. Ülkelerdeki işsiz sayısının artması ve yaşlı nüfus oranının toplam nüfus içindeki payının giderek artması sosyal güvenlik sistemlerini giderek çıkmaza sokmaktadır. Bu bağlamda birçok ülke sosyal güvenlik sistemlerini daha etkin kılabilmek için çeşitli reformlar yapmakta, politikalar geliştirmektedir.

Türkiye'nin sosyal güvenlik sistemi incelendiğinde, SGK'nın uzun yıllardır özellikle mali açıdan çok ciddi sorunlar yaşadığ 1 bilinmektedir. Literatürde, bu sorunlara ve çözüm önerilerine değinen birçok çalışma bulunmaktadır. Bu çalışmayı diğerlerinden farklı kılan nokta ise sosyal güvenliğe ilişkin değişkenler ile iller bazında analiz yaparak, daha detaylı bilgi vermesidir.

Çalışmada kullanılan MOORA Oran ve MOORA Referans yöntemlerine göre, Türkiye'de sosyal güvenlik açısından en etkin illerin İstanbul, Ankara, İzmir, Antalya ve Bursa olduğu görülmektedir. İki yöntemde sadece Antalya ve Bursa'nın yerleri farklı çıkmıştır. İlk beş ilin iki yöntemde de aynı olması, yöntemlerin güvenirliğine işaret etmektedir. Ayrıca İki yöntemde de üst sıralar incelendiğinde Marmara, Ege ve Akdeniz bölgelerine ait illerin ağırlıkta olduğu görülmektedir. Ayrıca Güneydoğu Anadolu Bölgesi'nden gelişmiş̧liği ile bilinen Gaziantep'in üst sıralarda olduğu görülmektedir. 
Genel olarak değerlendirildiğinde, analizden elde edilen sonuç, Türkiye'nin bölgeler arası gelişmişlik düzeyinin izdüşümü olarak görülebilir. Nitekim Üst sıralarda Marmara, Ege ve Akdeniz bölgelerine ait illerin, alt sıralarda ise Güneydoğu Anadolu ve Doğu Anadolu bölgelerine ait illerin ağırlıkta olduğu görülmektedir. İller arasındaki sosyal güvenlik etkinliği eşitsizliğinin minimize edilmesi açısından bölgeler arasındaki gelişmişlik seviyesinin minimize edilmesi, gelişmişliği az olan bölgelerde yatırımların ve teşviklerin çoğalması, işyeri sayısının artması kapsamında girişimciliğin teşvik edilmesi, hibelerin sayısının ve miktarının artırılması, bu bölgelerdeki işsizliğin azaltılması amacıyla asgari ücret desteğinin artırılması veya vergisel avantajların sunulması, havalimanı sayıları artırılarak bu bölgelerin ticari hacimlerinin büyütülmesi ve uluslararası entegrasyonlarının sağlanması gibi politika önerileri ifade edilebilir. 


\section{KAYNAKÇA}

AKTEPE, A., ERSÖZ, S. (2014). AHP-VIKOR ve MOORA Yöntemlerinin Depo Yeri Seçim Probleminde Uygulanması, Endüstri Mühendisliği Dergisi, 25(1-2), 2-15.

BALEŽENTIS, A., BALEŽENTIS, T., BRAUERS, W. K. M. (2012). Personnel Selection Based on Computing with Words and Fuzzy MULTIMOORA, Expert Systems with Applications, 39(9), 7961-7967.

BRAUERS, W. K. M., GINEVİČIUS, R., PODVEZKO, V. (2010). Regional Development in Lithuania Considering Multiple Objectives by the MOORA Method, Technological and Economic Development of Economy, 16(4), 613-640.

BRAUERS, W. K. M., ZAVADSKAS, E. K. (2006). The MOORA Methodand Its Application to Privatization in a Transition Economy, Control and Cybernetics, Systems Research Institute of the Polish Academy of Sciences, 35(2), 445-469.

BRAUERS, W. K. M., ZAVADSKAS, E. K., PELDSCHUS, F., TURSKIS, Z. (2008). Multi-Objective Optimization of Road Design Alternatives with an Application of the MOORA Method, ISRARC, 26-29 June, 541-548.

CHAKRABORTY, S. (2011). Applications of the MOORA Method for Decision Making in Manufacturing Environment, The International Journal of Advanced Manufacturing Technology, 54(9-12), 1155-1166.

DAS, M. C., SARKAR, B., RAY, S. (2013). On the Performance of Indian Technical Institutions: a Combined SOWIA-MOORA Approach, Opsearch, 50(3), 319-333.

ERSÖZ, F., ATAV, A. (2011). Çok Kriterli Karar Verme Problemlerinde MOORA Yöntemi”, KHO Savunma Bilimleri Enstitüsü Harekat Araştırmast.

GADAKH., V. S. (2011). Application of MOORA Method for Parametric Optimization of Milling Process, International Journal of Applied Engineering Research, Vol: 1(4).

GÖKBAYRAK, Ş. (2010). Türkiye'de Sosyal Güvenliğin Dönüşümü, Çalışma ve Toplum, 25(2), 141-162.

GÜVERCINN, C. H. (2004). Sosyal Güvenlik Kavramı ve Türkiye'de Sosyal Güvenliğin Tarihçesi, Ankara Üniversitesi Tıp Fakültesi Mecmuası, 57(02).

LEVENT, R. (2013), Dünyada ve Türkiye'de Sosyal Güvenliğin Gelişimi, İş ve Sosyal Güvenlik Mevzuat-Bilgi-Kültür-Haber Platformu, 23 Şubat 2013 Yazıs1, http://www.isvesosyalguvenlik.com/dunyada-ve-turkiyede-sosyal-guvenligingelisimi/ (Erişim Tarihi: 02.08.2017).

KARANDE, P., CHAKRABORTY, S. (2012). "Application of Multi-Objective Optimization on the Basis of Ratio Analysis (MOORA) Method for Materials Selection," Materials and Design, 37, 317-324.

ÖZÇELIKK, G., ATMACA, H. E. (2014). Satın Alma Süreci İçin MOORA Metodu İle Tedarikçi Seçimi Problemi, III. Ulusal Lojistik ve Tedarik Zinciri Kongresi, 15-17 Mayis 2014, Trabzon.

SOSYAL SİGORTALAR KURUMU (1999). İstatistik Yıllığg, Sosyal Sigortalar Kurumu Sincan Matbaas1. Ankara 2000: 2-13. 
STANUJKIC, D., MAGDALINOVIC, N., STOJANOVIC, S., JOVANOVIC, R. (2012). Extension of Ratio System Part of MOORA Method for Solving Decision-Making Problems with Interval Data, Informatica, 23(1), 141-154.

TEPE, S., GÖRENER, A. (2014). Analitik Hiyerarşi Süreci ve MOORA Yöntemlerinin Personel Seçiminde Uygulanması, İstanbul Ticaret Üniversitesi Fen Bilimleri Dergisi, 13(25), 1-14.

TURE, H. KOÇAK, D., DOĞAN, S. (2017). Multi-MOORA Yöntemi İle Ülke Riski Değerlendirmesi, Gazi Üniversitesi İktisadi ve İdari Bilimler Fakültesi Dergisi, 18/3, 824-844.

YILDIRIM, B. F., ÖNAY, O. (2013). Bulut Teknolojisi Firmalarının Bulanık AHPMOORA Yöntemi Kullanılarak Siralanmas1, Yönetim: Ístanbul Üniversitesi İsletme Iktisadi Enstitüsü Dergisi, 24(75), 59-81. 